\title{
Brief history of the Brazilian Platform on Biodiversity and Ecosystem Services/BPBES
}

\author{
Maíra de Campos Gorgulho Padgurschi ${ }^{1}$, Carlos A. Joly ${ }^{1,2}$ \\ ${ }^{1}$ Universidade Estadual de Campinas - UNICAMP, Campinas, SP, Brazil \\ ${ }^{2}$ Corresponding author: Carlos A. Joly,e-mail: cjoly@unicamp.br
}

It all started during the First Authors Meeting of the IPBES AMERICAS Regional Assessment in Bogotá (July 19 to July 23, 2015). The Brazilian group of experts assembled there saw an opportunity to think about producing a Brazilian Assessment, following the same concepts and structure established by IPBES for the AMERICAS. As a result, Carlos A. Joly (IPBES/MEP Member), Cristiana S. Seixas (Co-chair of the AMERICAS Regional Assessment), Fabio Scarano (CLA of Chapter 6 of the AMERICAS Regional Assessment), Jean P.B. Ometto (CLA of Chapter 5 of the AMERICAS Regional Assessment), Mercedes Bustamante (CLA of Chapter 4 of the AMERICAS Regional Assessment) decided to organize a meeting of Brazilian researchers already engaged on IPBES to discuss the viability of producing the First Assessment on Brazilian Biodiversity and Ecosystem Services under the premises and the Conceptual Framework of IPBES.

On November 2015, in Indaiatuba/São Paulo, the first meeting was organized with a group of 26 researchers (later named the core Group) already engaged with IPBES and with a representative of the Ministry of Environment. This meeting was supported by the BIOTA/FAPESP Program (São Paulo Research Foundation/FAPESP Research Program on Biodiversity ${ }^{1}$ ) and the Brazilian Foundation for Sustainable Development/FBDS ${ }^{2}$ (NGO) and resulted in the establishment of a Steering Committee as well as an outline of the proposed assessment, based on the chapter and content structure of the Americas Regional Assessment.

These consolidated results were presented and discussed with the Secretary of Programs and Policies Development from the Ministry of Science, Technology and Innovation and the unfolding was the submission, by Fabio Scarano and Carlos A. Joly, of a pledge for resources to develop the Brazilian Assessment on Biodiversity and Ecosystem Services. This pledge was approved in early 2016 and consisted of: 624 months post-doc scholarships, 624 month technical scholarships, plus money for organizing meetings (transport, lodging and food), development of a communication strategy and cost of diagramming, revision and printing the assessment to be delivered in June/2018. It also included the commitment of inserting all results of the assessment in the Brazilian Information System on Biodiversity $/ \mathrm{SiBBr}^{3}$. With the support of one post-doc (Young Fellows) each member of the Steering Committee became the CLA of one of the chapters and the work of preparing the assessment started immediately.

In parallel, Carlos Joly and Fabio Scarano had a meeting with the President of the Brazilian Society for the Progress of Science/SBPC ${ }^{4}$ (the Brazilian equivalent of the American AAAS) to discuss ways and means of establishing a permanent structure that could be recognized and embraced by Brazilian Researchers from all over the country. Previous

\footnotetext{
${ }^{1}$ www.biota.org.br

${ }^{2}$ www.fbds.org.br

${ }^{3}$ www.sibbr.gov.br

${ }^{4}$ http://portal.sbpcnet.org.br
}

experiences have shown that sometimes good proposals were dead at birth because they started under the umbrella of one or few States, and the support of such a traditional and respected organization was important to the success of the assessment. SBPC is an organization established in all Brazilian States, with regional secretaries, had the experience of leading a Working Group of Experts to discuss with the Brazilian Parliament changes in the Brazilian Forest Code (a battle that was lost to the interests of the agribusiness), and covers all areas of research, including natural and social sciences, humanities and economics, and thus important to have a balanced approach to the Brazilian Assessment on BES.

During 2016, the core Group wrote the white paper: "Contribution to an intersectoral dialogue: building a Brazilian Assessment on Biodiversity and Ecosystem Services" to be used as the basis for discussions with different sectors of society. With this first product, meetings were organized with Focal Groups. These groups represents different stakeholder: representatives of Non-Governmental Organizations, of different federal government organizations (Ministries of Environment; Science and Technology; Agriculture; Brazilian Foundation for Indigenous People), with ILK holders (indigenous students from a MSc Program focused on indigenous knowledge and rights), with representatives of the Private Sector, and others are still being organized. A common demand of all groups is the continuity of post-assessments activities, that is, that the assessment does not end in itself.

Once established as a Working Group of SBPC, and having the support of both Ministries, Environment and Science and Technology, but not directly subordinated to governmental bureaucracy, the Core Group started to invite researchers from all regions of Brazil and from different areas of knowledge, to work on the Brazilian Assessment. With the approval of the financial support by the Brazilian National Research Council (CNPq in Portuguese) until June 2019, the group decided to move on step forward and create the Brazilian Platform on Biodiversity and Ecosystem Services (BPBES).

Launched on February 2017 in São Paulo city, the Brazilian Platform on Biodiversity and Ecosystem Services/BPBES ${ }^{5}$ has the mission of producing regular assessments of the best available knowledge, by science and other knowledge systems, on biodiversity and ecosystem services issues, in a permanent dialogue with different sectors within society, and to be used to improve the interface between science and policy. Under the overall coordination of Carlos A. Joly and Fabio R. Scarano, BPBES now has six full-time postdoctoral fellows, six part-time technical fellows and 35 collaborator authors of the Assessment, in addition to the core Group. There are approximately 70 experts working in the five chapters of the Brazilian Assessment, since in the first authors meeting it was decided to merge chapters 3 and 4 (Chapter 3: Status, trends and future dynamics of biodiversity and ecosystems; Chapter 4: Direct and indirect drivers of change in biodiversity and nature's contributions to people).

\footnotetext{
5 www.bpbes.net.br/en
} 
Padgurschi, M.C.G. \& Joly, C.A.

At the same time, specific follow ups are being discussed in partnership with other Brazilian initiatives. The first of this kind, and following the same premises of IPBES, will be the topic Pollination, Pollinators and Food Production in Brazil, developed in partnership with the Brazilian Plant-Pollinator Interaction Network ${ }^{6}$ (REBIPP in Portuguese). This report will be delivered on July 2018 along with the first Brazilian Assessment on Biodiversity and Ecosystem Services. Two other similar initiatives are already under discussion: one for Inland Water (in partnership with the Brazilian Limnology Association ${ }^{7}$ ) and another specific for the private sector (through the Brazilian Business Council for Sustainable Development $-\mathrm{CEBDS}^{8}$ ).

${ }^{6}$ www.rebipp.org.br

${ }^{7}$ www.ablimno.org.br

${ }^{8}$ http://cebds.org/en/
Maintaining current rates of greenhouse gas emissions, projected effects of climate change on biodiversity and ecosystem services in Brazil by 2100 include loss of species in the order of $25 \%$, savannization of the Amazon, expansion of forests on the Brazilian Pampas, and impoverishment of the Caatinga, Cerrado and Pantanal. In addition, ocean acidification, coral whitening and sea level rise pose a risk to coastal and marine environments. Brazil has the opportunity to consolidate itself as the main model for sustainable development through the integrated vision of biodiversity and ecosystem services with socioeconomic and human development and the consequent incorporation into public policies in the country. BPBES wants to be a reference in the insertion of such themes as a strategic element of public policy, contributing to an innovative and sustainable model for socioeconomic development in Brazil. 